Article

\title{
Theodicy, Undeserved Suffering, and Compassionate Solidarity: An Interdisciplinary Reading of Hwang Sok-Yong's The Guest
}

\author{
Young Hoon Kim ${ }^{\circledR}$ \\ Graduate School of Theology, Sogang University, Seoul 04107, Korea; yhkimsj@gmail.com
}

Received: 3 August 2020; Accepted: 9 September 2020; Published: 10 September 2020

check for updates

\begin{abstract}
The author explores theological questions regarding the Korean novelist Hwang Sok-yong's The Guest from interdisciplinary perspectives. This paper analyzes the novel in relation to the emotional complex of han as understood in Korean minjung theology, the political theology of Johann Baptist Metz, and Ignacio Ellacuría's liberation theology. Drawing upon the perspectives of Korean, German, and Latin American scholars, this approach invites us to construct a discourse of theodicy in a fresh light, to reach a deeper level of theodical engagement with the universal problem of suffering, and to nurture the courage of hope for human beings in today's stressed world. Contemplating the concrete depiction of human suffering in The Guest, the paper invites readers to deepen their understanding of God in terms of minjung theology's thrust of resolving the painful feelings of han of the oppressed, Metz's insight of suffering unto God as a sacramental encounter with God, and Ellacuría's idea of giving witness to God's power of the resurrection in eschatological hope. The paper concludes that the immensity of today's human suffering asks for that compassionate solidarity with the crucified today which can generate hope in the contemporary milieu.
\end{abstract}

Keywords: han; hope; Hwang-sok Yong; liberation theology; minjung theology; political theology; The Guest; theodicy

\section{Introduction}

In a General Audience, Pope Francis earnestly invited all the people of God to pray for an inter-Korean summit on the occasion of the historic meeting between Moon Jae-in, the president of the Republic of Korea, and Kim Jong-un, the leader of the Democratic People's Republic of Korea (Pope Francis 2018). The Pope prayed with all the people of God in this short appeal for Korea "to build a better future" and "to have the courage of hope" that is "for the good of all." As this article was being written, the tension on the Korean Peninsula was still increasing due to sociopolitical uncertainties, just as it had been for seventy years since the Korean War in 1950. "As this peculiar situation has continued for 60 years, South Koreans have reluctantly become accustomed to a taut and contradictory sensation of indifference and tension" (Han 2017). Of course, many people all over the world need "the courage of hope." Both personal and collective suffering is rife in Afghanistan, Iraq, Palestine, Syria, and many other places. In the midst of the COVID-19 pandemic, the victims of war are particularly vulnerable to being treated unjustly. We are all tempted to become accustomed to the suffering of others, comforting them with cheap theological notions, or we simply turn our eyes away. Pope Francis thus speaks of "the globalization of indifference": we forget "how to weep" and "how to experience compassion-suffering with others" (Pope Francis 2013a). As a specific example of the courage of hope in the midst of human suffering, this article focuses on the pain experienced in the Korean War of the 1950s as recounted in the 2001 Korean novel The Guest. 
We explore this theme in the novel in terms of the Korean preoccupation with the emotional complex of han as understood in Korean minjung theology. The critical reflections of the German theologian Johann Baptist Metz also shed light on the urgent theological task of addressing the universal problem of suffering, and his reflections are helpful for understanding the religious thrust of the novel. He has said about Auschwitz, "Time and again since then I have asked myself why theology paid so little attention to human suffering and catastrophe" (Metz 1997, p. 33). Applying his question to the immense human suffering in our own age, the following question arises: How can we do theology without taking into account the particular historical realities in which God seems to be so far from human suffering? Borrowing his concept of "suffering unto God", we use this Korean novel as a concrete example of how an insightful author reflects on the question of how we can be drawn into others' suffering and transformed in compassionate solidarity. The Latin American liberation theologian Ignacio Ellacuria's insightful discussion of academic collaboration in the light of the crucified in every age likewise elucidates today's task of theology in a way that is pertinent to an understanding of the novel. In his words, "If in Latin America and in Europe, in San Salvador and in Deusto, the universities listen to and gather up the sufferings and hopes of a crucified humanity, then solidarity between the universities, and through them can be established, above all a solidarity among peoples and among the human beings of this world" (Sobrino and Ellacuría 1990, pp. 172-73). The Guest well exemplifies how we can dare to cooperate with one another to build solidarity with the crucified.

The overall worldview of The Guest is based on the fact that the suffering of the Korean War has been continuing in victimized persons up until the present. In the context of a Korean shamanic ritual that brings to light ghosts' memories of their suffering, the novel understands human suffering as an unjust experience. In the course of the ritual, that suffering is identified, resolved, and reconciled. By a theological reading of The Guest, the present author explores the text in relation to Korean minjung theology, Metz's political theology, and Ellacuría's liberation theology. The author does not intend to apply Metz's and Ellacuría's theologies to the Korean context from a one-way perspective but rather to explore them concurrently. In sum, minjung theology emphasizes the cry of the oppressed for justice, a cry that can lead either to hatred or to solidarity. Metz invites all to accept Christ and to participate in Christ's solidarity with the oppressed, within which solidarity God's presence is hidden. Latin American liberation theology stresses eschatological hope to decrucify the oppressed through the concretization of Christian witness. These ideas work together to illuminate The Guest in terms of their particular perspectives on human suffering. This interdisciplinary reading of the novel can create a privileged perspective for a theological exploration of the universal problem of suffering in the world. It has been said that for Metz "the contact with the reality and the theology of Latin America" enriched his theologizing. That contact provided the hermeneutical key of the "option for all those who suffer", embracing which option deepened for Metz "the web of connections between Latin American and Germany" (Prinz 2007, pp. 84-85). The present paper pursues the web of connections between Korea, Germany, and Latin America in search of mutual learning with the aim of nurturing the courage of hope for a better future.

\section{God, Too, Has Sinned: Theological Reading of The Guest}

Hwang Sok-yong's The Guest is based on a true story, the fifty-day nightmare experienced by 35,000 Sinchon citizens of Hwanghae Province, North Korea, who were categorized by North Korean Christians as communists during the Korean War. "Though a work of fiction," it has been said that "The Guest gathers empirical validation for the version of Sinchon it offers by employing several of the strategies associated with 'documentary novels'" (Ryu 2015, p. 641). One-fourth of the total population of Sinchon, including innocent women and children, were tortured and killed by crusading Christians of the town during those fifty days. Rev. Yu Tae-yeong, the real-life model for the main character, Ryu Yosop, has commented that "it's true that the North Korean state overly publicizes Sinchon, but considering the conditions of the time, I think this was the right move" (Ryu 2015, p. 
657). However, in a note within The Guest, Hwang Sok-yong points out that, just as when Koreans identified smallpox as a Western disease, referring to it as a "guest" and holding shamanic exorcisms to get rid of it, likewise he identifies Christianity and communism as Western ideologies that cause disaster and so he calls them "guests." He states that in this way he seeks to reveal the truth of both Christianity and communism, reconcile Western and Korean ideologies, and bring together North Korean Christians and communists (Hwang 2005, p. 9). In other words, he hopes to reconcile the mutual otherness of the past and the present, the living and the dead, and, most of all, the categories of indigenous and Western by examining the Korean War of 1950.

Ryu Yosop (Joseph), the main character of The Guest, is an American Presbyterian pastor who visits North Korea soon after the death of his brother, Yohan (Johann), who had committed a crime during the 1950 massacre and immigrated to the United States. Yosop goes to North Korea not only to bury Yohan's ashes in their hometown of Sinchon but also to apologize to the victims and their families for his brother's crime. During Yosop's journey, he encounters a series of ghosts of those who were killed by Yohan as well as the surviving victims. The author reveals this painful history in order to make reconciliation possible. By bringing to life the voices of the victims who were tortured and killed by their neighbors, his novel recounts the whole tragic episode and invites readers to understand what happened in the Korean War. The writer of the present paper aims to explore The Guest through the lens of remembering the suffering of that tragedy while at the same time being so bold as to offer hope for reconciliation between the victims and perpetrators.

The Guest is a narrative of memories of suffering. Yosop confronts two kinds of memory. One is public, while the other is private. The former is the official public representation of events as distorted by communist ideology. The latter is the sharp-edged truth of the personally lived experiences of female victims. Hwang gives expression to their experiences in and through the shamanic ritual in which the voices of the dead victims are brought to life and the living perpetrators can remember what they did in a way that eventually leads to reconciliation. As the author himself says, "This twelve-chapter novel is modeled after the Chinogwi exorcism of Hwanghae Province. The ritual consists of twelve separate rounds. As is the case during an actual exorcism, the dead and the living simultaneously cross and recross the boundaries between past and present, appearing at what seem like random intervals to share each of their stories and memories" (Hwang 2005, p. 7). These scars of the Korean War run so deep for both the living and the dead that the act of reviving the memory of the suffering is a great challenge to them.

At the beginning of the story, Yosop gives poetic expression to his unconscious reluctance to recall the memories of his hometown:

The moment he uttered Ch'ansaemgol, Yosop realized that some forty years had passed since he'd last mentioned the name of his hometown, Ch'ansaemgol. The word started out with the scent of a mountain berry, lingering at the tip of one's tongue-but then the fragrance suddenly turned into the stench of rotting fish. It was as if a blob of black paint had been dumped on a watercolor filled with tender, pale-green leaves, the darkness slowly seeping outward towards the edges. (Hwang 2005, p. 15)

For his part, while he was alive, Yosop's brother Yohan hardly ever spoke of the past. When he heard that Yosop was hoping one day to visit North Korea, he was suspicious of him and tried to convince him not to go. "Do you think it likely that God will allow you to go back to North Korea?" (Hwang 2005, p. 15). Yohan had even resisted Yosop's invitation to pray to God for forgiveness so that the dead could have peace. Yohan angrily shouts at him, "Why should I beg for forgiveness? We were Crusaders-the Reds were the sons of Lucifer! The hordes of Satan! I was on the side of Michael the archangel, and those bastards were the beasts of the Apocalypse! Even now, if our Lord were to command it, I would fight those devils!" (Hwang 2005, p. 24). During Yosop's journey in North Korea, too, this sort of hostile reluctance to confront the past continues. Yosop's nephew, Tanyol, who had remained in Ch'ansaemgol, cries out, "How dare you show up now, searching for your family! Do you have any idea how hard it's been for us, just to live from day to day?" (Hwang 2005, p. 87). 
However, the voices of ghosts from his boyhood remind Yosop that the absence of memory cannot erase the hurt from the brutal event embedded in the depths of the heart. "Even then, though, even if nobody else remembers, it's still there, deep down in your heart of hearts" (Hwang 2005, p. 205). In The Guest, the ghosts of the murderers and their victims are everywhere, telling their stories. Sometimes, they play an important role in the plot as the main protagonists, while Yosop seems to be a bystander listening to their voices and pausing for reflection. The ghosts of the dead show their willingness to discourse with the living, both victims and perpetrators: "The things you do in life, the good and the bad, may be dissolved when you die, but we should still go over what really happened before we leave" (Hwang 2005, p. 179). It has been said of the role of the ghosts that "Rather than serving as the ultimate barrier to the 'true past,' death is transformed into the ultimate guarantee of testimonial truthfulness. Since ghosts speak from beyond the grave, their utterances are seen as being free of motivations or failings all too human-faulty memory, as well as political, ideological, and libidinal investments" (Ryu 2015, p. 648). The ghosts' memories of the suffering connect in a narrative of the suffering that creates the whole fabric of a web of life, where the various first-person stories are interwoven like warp and woof.

The Guest raises a serious question about God and religion. It recounts the story of how crusading North Korean Christians rationalized their behavior, became morally depraved, and finally fell into religious madness. Thinking of the massacre, Yohan's wife speaks blasphemy: "God, too, has sinned, that's what I used to think. He looked down on this blazing hell, and he remained silent" (Hwang 2005, p. 142). Her words show that, as one of the victims, she is stuck in a sin-centered theology and a concept of God as the King in Heaven who "looked down on this blazing hell, and he remained silent." The Guest also challenges the reader with Yohan's perilous prayer that North Korean Christians prayed before killing communists:

Our Father in Heaven, we have guarded our faith under the oppression of the Communists, the enemy of the Holy Ghost. Thou hast told us to wear the armor of God, to become strong so that we can fight against the scheming designs of the devil. Thou hast shown us that the battle we wage is not a battle of flesh and blood but a battle for sacred service and divine power, a battle against the rulers of the dark world, against Satan, that evil spirit. The only way we will win this war is to rely upon the power of God and to prepare ourselves with the weapons of God. The Crusaders of freedom are just around the corner, coming to liberate our brothers in faith, but the army of Satan continues to threaten us. Let Michael, the Archangel, come among us and grant us the wisdom and courage that was once bestowed upon Joshua and David. The prayer complete, they all raise their heads. Each young man, like one enveloped by the flames of the Holy Ghost, burns with hatred and abhorrence-for Satan himself. (Hwang 2005, pp. 186-87)

Based on a dichotomy between good and evil, this prayer reinforces the Christians' abhorrence of the communists and rationalizes killing them. It shows how human madness can contaminate faith and how religion, as a dangerous and distorted ideology, contributed to the massacre. When Yohan and his companion Christians killed communists, they did so in the name of God's punishment. "All this is punishment, rained down upon you by our God" (Hwang 2005, p. 195). They thought of their commitment to the killing as an expression of God's punishment, and that kind of thinking empowered their commitment. Much worse, as Yohan admits, they had lost all sense of reality: "It was no longer the Lord's Crusade. We were no longer fighting to overthrow Satan. We have been tested, I thought to myself, and we have been found wanting. Our faith was corrupted. My comrades and I-we'd become the endless days, days without light. What does that mean, you ask? We were sick and tired of living. At the least provocation, we would spit out, Fuck it, and kill whoever happened to be involved" (Hwang 2005, p. 222). They were swallowed up into the violence by their own madness.

From a theological point of view, is it enough to know the facts of this historical event and the pain of the past? What message should theology deliver to those who are in such a hopeless state? Memory of the past and hope for the future go hand in hand. Let me revisit The Guest from the 
balanced point of view of memory and hope. The novel recounts Yosop's recollection of friendship with two communist girls from his childhood during the Korean War. He helps them hide from the security guards in the village and they become friends, but eventually they are killed by Yohan. In the course of building a friendship with them, Yosop sings a hymn to them: "This is my Father's world: I rest me in the thought of rocks and trees, of skies and seas; His hand the wonders wrought" (Hwang 2005, p. 210). The two girls play the violin for him, and he recalls the movements of his heart as he listened: "The violin seemed to sob more than ever at the crescendo, and the song's melody left me with a long, lingering aftertaste. My face burned, my throat soared, and, out of the blue, tears gushed out of my eyes. Sniffling, I wiped my face with my sleeve" (Hwang 2005, p. 212). He goes on to state his hopeful vision of a shared restoration of humanity: "Ah, suddenly, an entirely different world was opening before my eyes. Each of us must have been deep in our own thoughts; no one said a word" (Hwang 2005, p. 212). In this episode, the author of the novel presents an eschatological hope of Christians and communists living together. The ghost of Sunnam, who died at Yohan's hands, reminds Yosop of this hope. "There aren't any sides over there-no my side against your side" (Hwang 2005, p. 28). Much later, at the very end of the novel, The Guest concludes its story with joy and hope in a celebration of the shaman singing and dancing with the ghosts. "Behold today's feast, see our devotion, the ghost[s] of this land, the ghost[s] of this house, eat your fill, and know when to be silent. Fill your bellies, quench your thirst, eat your fill and pack up what's left-take it all with you, women on your heads, take it all with you, servants in your aprons-accept our goodwill, take some coin for the road and be on your way, up into the heavens" (Hwang 2005, p. 234).

What I want to stress in this study of The Guest is that theology needs to reflect and be based on concrete sociopolitical conditions where the cry of the suffering is heard. As a work of literature, The Guest effectively draws readers close to those who have been suffering and whose hope is thus endangered. This unpleasant reality poses a challenging question for theology. Jill Graper Hernandez captures the importance of discourse on theodicy when she says, "For a topic that many have thought long-solved, theodicy in the 21st-century has thus far produced novel approaches, uncovered new dilemmas, juxtaposed itself with other philosophical and religious fields, listened to new voices, and has even been done through uncommon methodologies" (Hernandez 2018, p. 1). How can present-day theodicy enter into the throes of solidarity and offer a credible account of hope? Motivated by this challenge, the present paper begins with the voice of the forgotten victims of The Guest to seek the theological seeds of hope potentially embedded in the ground of suffering to yield forgiveness and reconciliation.

\section{Han in Minjung Theology: A Hermeneutic Key to Understanding The Guest}

Let us explore the theme of The Guest through the lens of the Korean emotional complex of han in Korean minjung theology, or "people's theology." "While the term minjung can be literally translated as 'people,' it refers to 'those who are oppressed politically, exploited economically, alienated socially, and kept uneducated in cultural and intellectual matters'" (Kim 2018, p. 5). Minjung theology aims to interpret Korean han as a means to inculturize biblical notions in the context of Korean experience and history. Since feelings of han lie at the root of Korean identity, exploring the concept is an indispensable key to understanding the soul of the han-ridden people portrayed in The Guest.

There are many approaches to understanding and translating the complex meaning of the term han that the Korean language has borrowed from Chinese. The translator David Bannon has cited han as one example of "how not all concepts can be translated" and noted that "it is often preferable to leave the foreign word as is in an English translation" (Bannon 2008). The Taiwanese theologian, C. S. Song, speaks of han in the broad sense of a universal feeling of any soul experiencing suppression: "The rhythm of passion welling out of restless souls in the world of the dead, the wrongs done to them requited. Han is the rhythm of passion crying from the hearts of those who have fallen victim to social and political injustices" (Song 1986, pp. 70-71). The prominent minjung theologian Nam-dong Suh explains that "han is a deep feeling that rises out of the unjust experiences of the people. 
'Just indignation' may be a close translation of han, but it evokes a refined emotional yearning for justice to be done. Han is the suppressed, amassed, and condensed experience of oppression caused by mischief or misfortune so that it forms a kind of 'lump' in one's spirit" (Suh 1983, p. 58). The two theologians agree that han is the cry of the suffering for justice that can build solidarity.

Han has three aspects. First, han represents the transforming power that makes people create life and evolve. "It is the negative and destructive energy of pain and woundedness," writes Kevin Considine, "transformed into a positive and constructive energy expressed in love for self and others" (Considine 2014, pp. 53-54). It is the energy of affection that takes the form of sympathy, warmth, and friendship toward other people. Han can create solidarity among people precisely because they can not only share the common experience of this deep feeling but also resist evil through sharing.

Second, han is an evil force that makes people suffer and entangles them in bondage and hatred. $H a n$ can drive people to vengeance because of hatred. Of $h a n$ 's theological meaning in relation to Korean identity, Chung Hyun-kyung says that "han comes from the sinful interconnections of classism, racism, sexism, colonialism, neo-colonialism, and cultural imperialism which Korean people experience every day" (Chung 1989, p. 138). What kind of relationship might exist between han and sin? "Sin produces han, and han often produces more sin, which produces more han in what becomes a vicious cycle" (Joh 2006, p. 102). Does the sinfulness belong only to the oppressor and han only to the oppressed? "Sin and han are part of both the oppressors and the oppressed ... Most oppressors have become oppressors because of their experience of han ... These two aspects, sin and han, contribute to each other in a cyclical relationship" (Joh 2006, p. 102). There is, thus, an intertwined chain of the evil of han and $\sin$ in a vicious cycle that preys on a victim.

Third, Sandra So Hee Chi Kim sees han as a dual positive-negative force: "Han is the word for sorrow in reaction to historical injustice against those who identify as Korean. Han is an example of how history becomes internalized in individuals while at the same time creating horizontal connections of empathy and identification" (Chi Kim 2017, p. 274). For native Koreans, han can entail a heartfelt hope to overcome conflict and bear fruit in healing and eventually mutual reconciliation. The prominent South Korean novelist Park Kyong-ni identifies han as the soul of a Korean: "It means both sadness and hope at the same time. You can think of han as the core of life, the pathway leading from birth to death. Literature, it seems to me, is an act of han and a representation of it ... Han, which comprises both sadness and hope, is a feeling unique to the Korean people" (Park 1994). Although such stirrings of han may not be unique to Koreans, they serve Koreans well by allowing them to risk love and preserve hope in the midst of suffering.

\section{Revisiting The Guest from the Perspective of Han in Minjung Theology}

The question then arises of how han, as understood in minjung theology, gives rise to the hope of those who are victimized in the tragedy of The Guest. As we have noted, the novel consists of twelve chapters aligned with the structure of the traditional North Korean shamanic Chinogwi ritual of Hwanghae Province, in which "twelve separate rounds take place where the dead and the living simultaneously cross and recross the boundaries between the past and the present" (Suleski 2007, p. 292). This rich ritual tradition helps a family who has lost a loved one to release negative currents of han and restore their fractured relationships by using its positive potential. The "shamanistic gut [ritual] gave the opportunity for the voiceless ghosts to speak out their stories of han. The community then must solve the han of the ghost collectively either by eliminating the source of oppression for the ghosts or by comforting or negotiating with the ghosts" (Chung 1989, p. 143). Through this sacred ritual called Han-pu-ri (releasing han), both the victims and the persons who caused their suffering are mutually reconciled and come to experience a renewal of hope.

From the theological point of view of minjung theology, this ritual transformation of han can be a Paschal experience of passing from death to life and embracing renewed life. Andrew Park Sung articulates this view of han by pinpointing its initially negative character: "The crucifixion signifies the Han-pu-ri (resolving han) of God for the suffering people. The cross is God's ultimate negation of the 
han of the afflicted. The resurrection of Christ as the negation of the negative connotes God's ultimate affirmation of the hanless nature of a new heaven and a new earth" (Park 1989, p. 60). In other words, the event of crucifixion constitutes the peak of God's salvific will in transforming han. The cross is God's manifestation of divine love for han-embroiled human beings; the resurrection is God's expression of hope beyond the bonds of han. Christ's death and resurrection thus embody the transforming power of han from grief to hope and mutual solidarity. This is possible because han is not limited to sin but extends to a transformative potential of exposing the dynamics of the vicious cycle and structure of evil. Basically, han is human suffering. Christ does not bypass the ineffable pain of our suffering but chooses to share human weakness to the extent of being exposed to han. This is Christ's own way of love, sharing in victims' suffering. This theological understanding of han within the Paschal mystery is most important. Otherwise, han remains in a limbo of simply vague human hope.

By telling the story of the han of both the victims and oppressors in the bloody events of the North Korean village of Sinchon, The Guest recreates the experience in a way that uncovers, shares, releases, and transforms han into a source of salvation. This han brings to life the memory of the historical slaughter in a way that invites readers to share in bearing the woundedness in all of us. While listening to the voices of the ghosts as they vent their han-filled memories, Yosop says to himself, "Ah, finally they're all through with their stories. But no, it's not over yet, Yosop thought" (Hwang 2005, p. 102). The gentle but quite coercive strategy of the literary character Yosop brings readers face to face with the unimaginable historical reality of the forgotten victims. Their memories engage readers with the brute fact of suffering. "Even then, though, even if nobody else remembers, it's still there, deep down in your heart of hearts" (Hwang 2005, p. 205). At the end of the novel, the protagonists have their own transformative experience of han. One of the ghosts of the dead, Yohan, says, "Finally, I am relieved of 'han'. Finally I see my friends, and finally, I can stop wandering through unknown darkness. I'm off. Be well, both of you" (Hwang 2005, p. 225). He then poetically describes his experience of the whole inner journey. "Silence descended. The darkness was gradually withdrawing; daybreak was on its way-outside the window, beyond the distinct shadows of the mountain ridge, the milky sky was growing clearer" (Hwang 2005, p. 225). Yosop takes time for reflection and seemingly invites readers to ponder the suffering that the citizens of Sinchon have experienced. "He gazed at himself as he was, reflected dimly on the windowpane. It was the face of the most familiar man in his whole world" (Hwang 2005, p. 232). He thus raises a question to the readers of their ongoing witness to the transformative experience of han in words that call to mind what Paul says in 1 Corinthians: "For now we see in a mirror, dimly, but then we will see face to face. Now I know only in part; then I will know fully, even as I have been fully known. And now faith, hope, and love abide, these three; and the greatest of these is love" (1 Cor 13:12-13 NRSV). On the whole, The Guest raises Yosop's question to readers as it recounts his and Yohan's transformative experience of han through which they are liberated from their suffering. As seen from the perspective of minjung theology, the souls of the han-ridden minjung of the novel play the role of transvaluing their previous experience of han and revealing genuine hope for human salvation.

\section{The Guest from the Perspective of Theodicy as Raising the Question of God in the Face of Suffering}

It has been said that questions of theology should be related to the world's tragedies. "According to Johannes Metz, the question for theology after the genocide of the Jews by the Nazis in World War II was how to justify God, a question strictly speaking of theodicy, the question for the tragedy of Latin America and other tragic lands and poles is how to justify the human beings who have been the cause of so much tragedy, or who have been the 'shuffling bystanders' who look away" (Crowley 2017, p. 67). Metz himself speaks of his concern for talking about God after Auschwitz as follows: "As I became conscious of the situation after Auschwitz, the God-question forced itself on me in its strangest, most ancient and most controversial form, as the theodicy question; not in its existential but, to a certain degree, in its political garb: discourse about God as the cry for the salvation of others who suffer 
unjustly, of the victims and vanquished in our history" (Metz 1998, p. 55). Gustavo Gutiérrez, mindful of Metz's theological reflections on human suffering, articulates the question more sharply:

We must, therefore, ask: How can we talk about God without referring to our own age? More than that: How can we do it without taking into account situations like the holocaust in which God seems to be absent from immense human suffering ... How are we to speak of the God of life when cruel murder on a massive scale goes on in "the corner of the dead"? How are we to preach the love of God amid such profound contempt for human life? How are we to proclaim the resurrection of the Lord where death reigns, and especially the death of children, women, the poor, indigenes, and the "unimportant" members of our society? These are our questions, and this is our challenge. (Gutiérrez 1987, pp. 101-2)

Turning to my own project, I ask myself how I can do theology without taking into account a situation narrated in The Guest, in which God seems to be so absent from immense human suffering?

For Metz, danger is the starting point of theology; authentic Christian hope begins with what he calls the "dangerous memory" of Jesus Christ (Metz 1998, p. 47). Borrowing an idea of Origen, he recalls what Jesus said: "Whoever is close to me, is close to fire; whoever is far from me, is far from the Kingdom" (Metz 1998, p. 47). In this way, "it is dangerous to be close to Jesus, it threatens to set us afire, to consume us" (Metz 1998, pp. 47-48). Metz thus understands that the perception of danger defines Christian identity. He explains that the memory of Christian faith means the "dangerous memory" of Christ's death and resurrection. "Memoria passionis, mortis, et resurrectionis Jesu Christi, the memory of the crucified Lord stands at the heart of this faith, a specific memoria passionis, which forms the basis of the promise of a freedom that will come for everyone" (Metz 2007, p. 107).

Inspired by this dangerous memory, Christians bear, in Metz's schema, the eschatological hope "in the God of Jesus as the God of the living and the dead, who calls all to be subjects in God's presence" (Metz 2007, p. 81). Since the notion of danger is Christ-centered, for Metz Christian hope is rooted in a radical following and imitation of Jesus: "To follow Jesus means ultimately not only to admire him, to take him as a model ... but something more radical and more dangerous: putting him on, putting Christ on" (Metz 1978, p. 34). Metz attempts to make use of the Incarnate Word of God, in particular his incarnation in the poverty of the human condition, as a Christian manifesto. Living out of the remembrance of Jesus' poverty in spirit implies that being deeply sensitive to human suffering as gained through the experience of his passion and death is the true purpose of human existence.

Metz invites his readers to encounter the face of the passion of Christ in the world through the face of the suffering of others. Jesus' statement, "Just as you did it to one of the least of these who are members of my family, you did it to me" (Matt 25:40 NRSV), provides the key to approaching both the passion of Christ and the suffering of others. Jesus identifies himself as one of the least of his sisters and brothers, and his figure can be found hidden in the poverty of his least sisters and brothers. Here, the punch line is that "Jesus was no stranger to this poverty either. He was a beggar, knocking on people's doors ... He had no place to lay his head, not even in death-except a gibbet on which to stretch his body" (Metz 1968, p. 38).

Jesus Christ himself has been with us as the least of his sisters and brothers. He understands our difficulties very well, as is evident by his identifying characteristics: hunger, thirst, living as a stranger or itinerant, nakedness, and imprisonment. He is not absent at all, but rather is present as one hidden in the neediest ones. As Metz puts it, "the suffering of Christ" and the "suffering of others" eventually lead to "the suffering of Christ in humanity" (Prinz 2007, p. 158).

In general, Metz's theology is located in the theodicy that focuses on suffering human beings. "For me the theodicy question, the basic theological question ... I begin not with the question, 'What happens to me when I suffer, when I die?' but rather with, 'What happens to you when you suffer, when you die?" (Downey and Metz 1999, p. 137). For him, it is totally engaged in the current political situations of our neighbors: "The only image of God is the face of our neighbor, who is also the sibling of God's First-Born, of God's own likeness (2 Cor 4:4; Col 1:15). Our human neighbor now becomes a 
'sacrament' of God's hidden presence among us, a mediator between God and humanity" (Metz 1968, p. 32). Aware of Jesus Christ's hidden presence, living for others on our part brings hope. On this basis, Metz makes a bridge from the dangerous memory of Jesus to the question of Christian hope.

Christian hope is essentially directed to the world of our brother, since this hope fulfills itself in love for the other, for the least of our brothers. Only in this kenosis of love is death overcome. "We know that we have passed out of death into life, because we love the brethren" (1 Jn 3:14). The Christian hope enters into the passion of death in this kenosis of love to the least of our brothers. This is the imitation of Jesus: he did not live for himself, but for us. Hope is this living for "the other." (Metz 1969, p. 97)

Only if we are willing to see our neighbors as embodying the presence of Jesus Christ can there be eschatological hope for the future togetherness of the living and the dead.

\section{Cultivating Prayers of Lamentation: Revisiting The Guest from Metz's Theological Understanding of Hope}

If Metz and the protagonists of The Guest were to meet for discussion, what would they have to say to one another concerning God and hope? If we compare the question of God in The Guest with Metz's theodicy question, we find that while some victims in the novel understand God as one who "looked down on this blazing hell, and he remained silent" (Hwang 2005, pp. 142-43) in the massacre, Metz would understand the God of the novel as sacramentally suffering in the victims so that allows their suffering to be for them "suffering unto God" (Metz 1998, p. 42). In a discussion with Elie Wiesel about the Holocaust, he explains that the concept of "suffering unto God" points to a "particular form of omnipotence, namely, the omnipotence and invincibility of God's love" (Schuster and Boschert-Kimmig 1999, p. 47). For example, Wiesel's Holocaust account Night tells the story of a young boy's death by hanging. For Wiesel, God is hanging on the cross (Wiesel 1969, p. 76). All who suffer are a sacrament of God's presence. God seems absent because he is invisible in the midst of suffering, but God is present because he is hanging on the cross. In The Guest, the boy Yosop takes the risk of helping two communist girls who are in anguished flight. Metz would say that God is omnipotent because God is hidden but should be sought among such persons in anguish who are actually a sacrament. He could very well add what he has stated in his discussion with Wiesel: "After all, at its roots suffering is anything but a powerful or even triumphant and solidaristic co-suffering. It is not even simply a sign and expression of love; rather, it is much more a horrifying sign that one is no longer able to love. Suffering leads into a void unless it be suffering unto God" (Schuster and Boschert-Kimmig 1999, p. 48).

In The Guest, the wife of Yosop's brother includes in her prayer the exclamation, "God, too, has sinned" (Hwang 2005, p. 142). Her prayer would undoubtedly remind Metz of "an incessant eschatological turning of our questions back unto God" (Metz 1998, p. 67). Since the Sinchon massacre happened, she has been struggling with the loss of her daughters and being left alone with God to bear her despair and sorrow. For Metz, however, prayer is not about God but to God. He says, "We should face up to our fears and doubts and consider in all seriousness the nature of the God to whom we direct our prayers. Is this silent, faceless God not an indifferent idol, a Baal, a Moloch? Is he not an unbearable tyrant enthroned in an elevated realm to which our longings and sufferings have not entry?" (Metz and Rahner 1980, p. 21).

Actually, "God, too, has sinned" may very well be a prayer of lamentation to God. Yohan's wife is not talking about God but talking with or to God. Let us go back to Yosop's dialogue with her.

His sister-in-law bowed her head for a moment. Then, in a small voice she said,

"Would you say a prayer and read from the Bible for me?"

"Even now ... you still believe in God?"

She glanced quickly in the direction of the bedroom. Her voice hushed, she replied, 
"There are times when I still pray ... once in a while, when I think of my father."

"What kind of ... what do you say ... in your prayers?"

"God, too, has sinned." (Hwang 2005, p. 142)

For Metz, "the most appropriate linguistic form for this type of experience of God and speaking about God is the language of prayer" (Losada-Sierra 2019, p. 13). Particularly, the language of prayer is such a cry of lament. "The language of prayer is familiar with the painfully enigmatic character of human existence, of how problematic it is in view of God ... It often ends in a single cry, or even in nothing but a voiceless sigh of the creature" (Schuster and Boschert-Kimmig 1999, p. 43).

Nonetheless, Kathleen O'Connor describes Jeremiah's Lamentations as a form of hope in that the afflicted one is still able to pray to God: "[The book of Lamentations] prays hopefully because it neither dodges truth nor lets God escape unchallenged into the cloudy heavens. In the face of pain and suffering, the speakers pray anyway. They challenge God and demand justice" (O'Connor 2002, p. 127). For Metz, appropriate biblical models of prayer are Job as he wrestles with God and Jesus as he admits fear before facing the cross in the Garden of Gethsemane. Metz would surely see lamentations and seeming blasphemy of the prayer of Yohan's wife as such a model of prayer.

For Metz, moreover, suffering unto God draws us to the suffering of others. He has raised a relevant question: "Was Christianity too exclusively a sin-sensitive religion that consequently understood itself too little as a religion sensitive towards suffering?" (Prinz 2007, p. 80). In Metz's view, "to be a follower of Christ," "to be called forth," "exodus," "lifting up one's hand," "conversion of the heart," and "discipleship" are almost synonymous (Metz 2007, p. 131). He thus understands that not only is prayer offered to God but it also allows entry into sufferers' hearts and being with them. Prayer is "mysticism of open eyes, which commits ... to an increased awareness of the suffering of the stranger" (Prinz 2007, pp. 152-53). Metz focuses prayer on participation in others' sufferings. "Prayer as pleading, as asking God for God, is an intrusion, an entering into the mysticism of suffering with 'the other,' of compassion. It is not the mysticism of distant or closed eyes, but rather the mysticism of open eyes" (Prinz 2007, p. 155). For him, then, witnessing the dangerous memory of Christ and prayer of lamentation are two sides of the same coin.

The prayer of lamentation helps Christians to cultivate hope for others with a renewed vision for the Reign of God. If Metz, being sensitive to the suffering of Yohan's wife and her prayer, would meet for discussion together with the protagonists of The Guest and present-day Christians, he would surely encourage Christians to have solidarity with her lifelong suffering out of service to Christian eschatological ideals of continued hope and out of witness to the memoria passionis that has the power to lead to a hope-filled union with the Paschal mystery of Jesus Christ.

\section{The Guest from the Perspective of Ignacio Ellacuria's Understanding of Hope as Manifested in the Contemplation in the Action of Justice}

Minjung theology as articulated by Nam-dong Suh discusses the Korean complex of han in such a way as to serve people who are politically oppressed or economically exploited, while Metz's mystical-political theology invites us to face the suffering of the poor in light of Christ's passion. The former applies a contextual approach to people's oppression by identifying their sociopolitical experience with Biblical texts. The latter focuses on what J. Matthew Ashley has called "an attempt to define a stance toward the world and history, articulated with new conceptual tools, for which the concrete catastrophes of history would be an irritating, interruptive presence internal to faith and for which theology would be constitutionally on the lookout" (Ashley 2003, p. 123). The question arises, then, as to the praxis of how to take the oppression and suffering of crucified people on ourselves on the one hand and how to take them down from the cross on the other. This is the key question raised by Ignacio Ellacuría in his analysis of the Spiritual Exercises of St. Ignatius. For Ellacuría, Jesus has been dying up until the present in the crucifixion of ordinary people; Christian hope for the crucified victims of the world is found in Jesus' resurrection. 
As Ellacuría sees it, the Spiritual Exercises invite us to contemplate the compassionate incarnation of the Word in this world of crucified people and as concrete Christian praxis to take a stand against the ongoing crucifixion brought about by unjust social structures. As Louis J. Puhl translates Ignatius's text, the three Persons of the Trinity say, "Let us work the redemption of the human race" (Puhl 1968, p. 50). As Ellacuría himself describes the event of the Word becoming man, "It incarnates that in Jesus which makes the Father visible" (Ellacuría 2010, p. 231). However, God's presence is not limited to God's sole incarnational endeavor; it is open and needs human cooperation with God. "A human presence and an historical action is always necessary to make God present" (Ellacuría 2010, p. 219). Ellacuría thus challenges those who want to follow Jesus Christ to make the compassionate love of God present by giving witness to God's presence in the crucified world. "The crucified people are ... the linking force among his concepts of discipleship, martyrdom, and oppression" (Hogue 2018, p. 4). Indeed, Ellacuría was so faithful to be a disciple of Jesus to live and die for the oppressed even to the point of martyrdom.

To help realize this challenge, Ellacuría urges exercitants to apply what St. Ignatius calls "the composition of the place" to their particular historical-political context of the crucified people. Ellacuría asserts that the Spiritual Exercises provide the theological place for such historicization: "They pave the way for its reception based on one's own situation. What is more, they historicize this word of God insofar as they turn to historical, personal, and circumstantial signs to enable that word to be discovered in the concrete" (Ellacuría 2010, p. 208). Similarly, Latin American theology has urged that exercitants apply this kind of composition of place to their praxis. As Ellacuría says, "The third world demands that we incarnate the experience of the Exercises right now, and it offers us the best conditions for doing so" (Ashley 2010, p. 193). This is a way for human beings to make the love of God expressed in the divine Incarnation present now. As Ashley explains, by deepening this composition of the place urged by Ellacuría, we are "putting ourselves in touch with the reality of Jesus" manifested through the crucified (Ashley 2000, p. 36).

According to Ellacuria, the praxis of conversion for others can be realized through a consideration of $\sin$ in the first week of the Spiritual Exercises. St. Ignatius invites exercitants to converse with the crucified Christ, asking, "What have I done for Christ? What am I doing for Christ? What ought I to do for Christ?" (Puhl 1968, p. 28). For Ellacuría, this colloquy plays an important role in the Exercises: "Only open your heart," Ellacuría says, "your Christian heart, and ask yourselves the three questions Ignatius of Loyola put to himself as he stood in front of the crucified world" (Ellacuría 2010, p. 241). The colloquy helps the exercitants to perceive the reality of the sufferer as well as the reality of the Word of God. Ellacuría articulates further the reality of the crucified by paraphrasing the question: "What have I done to crucify them? What am I doing in order to uncrucify them? What ought I to do so that this people will be raised?" (Burke 2004, p. 26). The more deeply the exercitants realize that crucified people are hanging on the cross as the crucified Christ in the present reality, the more eagerly do they respond actively to that suffering. It is precisely in this place (lugar) that the Exercises lead the exercitants to be one with crucified human beings through the lens of the crucified Christ. As Kevin Burke has stressed, "Ellacuría observes that anyone who reflects as a believer on the mangled reality of this crucified people must ask what it implies regarding sin and the necessity of salvation" (Burke 2004, p. 183). Those who want to follow Jesus Christ need to deepen in their heart commiseration of the plight of crucified victims as the salvific work of the crucified Christ.

As Jon Sobrino has pointed out, the fundamental question Ellacuría raises is that of service for others: "What should I do to seek God's will in all things and carry it out?" (Sobrino 2006, p. 4). This question challenges Ellacuría to confront taking crucified people down from their crosses. The question is about praxis: action for the "service for others" who give "meaning to his life, and who taught him how to serve" (Sobrino 2006, p. 5). Ellacuría examines the question further in terms of the Jesuit ideal of contemplation in action: "Contemplation requires special moments in which to gather up and consciously deepen the confrontation between the word of God heard in revelation and the urgent problems that come from reality through the mediation of centered reflection" (Ellacuría 1993, p. 286). 
He means that as one gets a grip on the internal knowledge of the reality of the unjust structure of society from the appropriate stance of the colloquy, one can truly be contemplative in action. For Ellacuría, contemplation means "the real possibility of encountering God in creation and the possibility of recovering creation as the presence of God" (Ashley 2006, p. 155).

The main question is what kind of action can leave room for true contemplation. Ellacuría finds the reply in the historical work of Christ: "Contemplation will not be true unless it is realized within that action that is really demanded by the historical following of the historical Jesus" (Ashley 2010, p. 200). True contemplation cannot be separated from the lugar of crucified human beings and service to them. Therefore, as Ashley has noted, contemplation in action for Ellacuría is "contemplation in the action of justice" (Ashley 2006, p. 154). When we resist the unjust structures of society, we can find God in our labor. As Ellacuría himself says, "What is involved is a contemplation of God in things that gives way to contemplation in action with things in which God becomes present to the person at work, and the person makes God present and becomes present to a God at work" (Ashley 2006, p. 155). Contemplation in action thus signifies a mutual relationship. In places where human needs are urgent and serious, God is asking for our cooperation as comigo. It has been said that "Ignatius uses the Spanish word 'comigo,' meaning 'with me.' It is an intimate word. We are working alongside Christ. Our being with Christ precedes but includes our working with Christ. In order to be Jesus, we find ourselves working alongside him" (Fleming 2008, pp. 68-69). This meaning of contemplation in action brings it into relationship with suffering human beings in a mission of serving them by bringing them down from their crosses.

\section{Suffering is a Call to Conversion: Revisiting The Guest from Ellacuria's Point of View}

In The Guest, Yosop departs from the United States, where he now lives, to go to his hometown in North Korea, the place of others' crucifixion. This pilgrimage enables him to be incarnated in the historical site of the Sinchon massacre. During the journey, his encounters with living and dead victims draw him to confront both personal and structural sin. In the course of the shamanic ritual there, two ghosts of victims and perpetrators tell him what really happened in that place: "We thought we'd come by and clarify a few things" (Hwang 2005, p. 109). Through their eyes, readers revisit the historical event. In Ellacurían terms, this is a lugar of the third world in which God's hidden presence can be unearthed.

Yosop's prayer expresses the fact that the tragic place of Sinchon is, nonetheless, a home of souls: "Our Father in Heaven, I have returned to my home ... I have seen with my own eyes that this land, too, is still a home for souls. Thou hast not forsaken-I know this now. Please, Lord, help us to not resent the suffering we caused each other in days long past. Help us to forgive one another" (Hwang 2005, p. 143). His prayer calls attention to the fact that God's salvific grace has broken into human sinfulness. As Burke has said of Ellacuría's understanding of the relationship between sin and grace, "With the eyes of faith, the believing community thus grasps that the poor themselves, impoverished and oppressed by injustice, have become the preferred locus of benevolence and grace, of God's faithful love" (Burke 2004, p. 182). For Ellacuría, the contemplation to attain love of the Spiritual Exercises points to the fact that the world continues to be the lugar where God is present even though there is still sin in the world (Ellacuría 2010, p. 236).

The question remains, what is one's own specific place in a particular context, the place of crucified people where the call to conversion needs to be asked? For Yosop, it is Sinchon. For Ellacuría, explains Ashley, the Spiritual Exercises allow one to have a "theological experience" in which "she or he continually discerns and chooses to incarnate herself or himself actively in history, thereby continuing the presence of Jesus in history by following him —which is to say, by 'historicizing' God's saving presence" (Ashley 2010, p. 197). The Guest recounts not only that Yosop allows his brother Yohan to become reconciled with the living and dead victims but also that he himself is in turn transformed by encountering the sufferers in that particular lugar. For Ellacuría, encountering forgotten historical realities of sin demands a conversion of the human heart. The wife of Yohan exemplifies such a 
conversion when she shows compassion for both the victims and perpetrators of the massacre: "The people your brother killed-well, they all had souls. They weren't Satan. Ryu Yohan wasn't Satan, either. His faith was twisted, that's all. I know now" (Hwang 2005, p. 109). As Burke has noted, Ellacuría says that "given the historical reality of individuals and peoples, compassion is very often the form in which faith, hope, and love present themselves; a mercy and a compassion that is preferential towards the most weak, but which extends itself universally to all humans because all human beings are the children of sin and, at the same time, the parents of sin" (Burke 2004, p. 191). In this vein, the character Ahn Sung-man in The Guest rebuts Yosop, who thinks of everyone as innocent of sin: "Show me one soul who wasn't to blame!" and then prays, "I pray for us all, for our salvation" (Hwang 2005, p. 162). Ellacuría would understand his prayer as an expression of hope in God's power of the resurrection that needs to be sought again today, not simply as a passive transformative experience, but as an enhanced personal commitment to the greater love and service of others.

Nonetheless, Yosop plays the important role of vindicating the dignity of the victims and even hoping for reconciliation by bringing to ritual life their collective memory of han. He hears the cries of the ghosts, one bemoaning, "We hate ourselves" (Hwang 2005, p. 224), and another, earlier, lamenting that they are "stuck wandering around this world" (Hwang 2005, p. 109). The novel states that "Yosop knew only too well that their testimonials were all fabrications" (Hwang 2005, p. 99), but it makes the expressions of the victims' memories audible and the forgotten figures of the survivors visible. The character of Yosop serves not only to comfort their souls but also to unveil the sociopolitical structures of sin by exposing the sinful ideological investment on the part of the Sinchon villagers, communist and Christian. As Youngju Ryu has pointed out, by following Yosop's account, readers ponder the fact that the tragedy of the Korean War has been continuing in the division of the Korean Peninsula, on which all people are still victimized and remain unreconciled (Ryu 2015, p. 659). The publication of The Guest has served to draw the attention of the people of South Korea to the crucifixion of their brothers and sisters years ago in Sinchon. In Ellacuría's theological schema, the novel can serve to move people to rephrase the Ignatian colloquy in their situation: "What have I done to crucify the victims of the Korean War and perpetrate the division of Korea? What am I doing to uncrucify this people and dismantle the sinful structures of the present Cold War on the Peninsula? What ought I do so that this people can be raised?" This is the Christian mission, and more importantly, the Christian courage to hope.

\section{Conclusions}

How can we practice sound theology based on a lived experience of God's continued relation to human suffering? How can theology nurture the Christian horizon of hope in the midst of suffering for both victims and perpetrators? The Korean theologian Jung Young Lee has proposed an apt answer: “Theology begins with my life, but my life is related to the lives of others. Thus, 'I am' is always also "we are'" (Lee 1995, p. 8). In line with this, the present author underscores that sound theology encompasses Christian hope together with all the people of God based on oori (our) experience and yet not limited to what we ourselves have experienced, but as we mutually learn and teach as we move together toward hope and solidarity. From a circular point of view, by exploring The Guest, my story is our story and our story is also my story. We are all connected with one another and interdependent. From the perspective of what I would like to call our "web of relationships in God," sound theology helps us to feel compassion for those who are suffering and receive from them in turn the gift of hope.

However, we are all too vulnerable to averting our attention and closing our eyes in the face of the suffering world. The passage of Matthew 25:40 that Metz refers to is a good antidote to a world filled with temptations to lose hope: "Just as you did it to one of the least of these who are members of my family, you did it to me." For Metz, as he reflects on these words of Jesus, people who are suffering remind us of Christ hanging on the cross, and Christ on the cross reminds us of the people who are oppressed and repressed. For Ellacuría, borrowing the schema of death and resurrection from the Spiritual Exercises, crucified victims represent the crucified Christ where God is hidden and yet present. 
The theological reflections of these two theologians invite us to deepen praxis so as to follow Jesus Christ by identifying with and caring for "the crucified people" suffering all over the world here and now. As Pope Francis has put it, "Jesus, the evangelizer par excellence and the Gospel in person, identifies especially with the little ones (cf. Matt 25:40). This reminds us Christians that we are called to care for the vulnerable of the earth" (Pope Francis 2013b). God is omnipotent in the least of our brothers and sisters who are a "sacrament" of God's hidden presence, the body of Christ among us.

Compassion produces hope-charged praxis. Metz rightly says, "Only if we are willing to see ourselves with the eyes of 'the other,' as 'the other' sees and judges us, will there be hope for a path of political understanding and reconciliation" (Prinz 2007, pp. 161-62). This kind of compassion nurtures the courage of hope, in Ellacuría's words, "as the human person's openness and movement toward a future to be made, and as hope in a promise, made definitive in Jesus, that the Reign of God will come because in some way it is already here" (Ellacuría 2013, p. 284). If we understand compassion as "the eyes of 'the other,'" Jeong, a Korean expression of compassion, sheds great light on this movement of the heart. "Jeong embodies the invisible traces of compassion in relationships" and "Jeong is the power embodied in redemptive relationships" (Joh 2006, p. xxi). This kind of compassionate relationship with crucified persons moves us to communicate with our hearts, manifesting love in deeds, and generating hope for them. Ellacuría has identified the task of a Catholic university with relation to the Ignatian colloquy: "Only open your human heart, your Christian heart, and ask yourselves the three questions Ignatius of Loyola put to himself as he stood in front of a crucified world." (Sobrino and Ellacuría 1990, pp. 150-51). Applying this counsel to the immensity of human suffering, one can realize that Jesus Christ, hidden in the present reality, invites us to seek Him among the crucified and that for the fulfillment of His salvific plan, He is waiting for Christians' praxis in response to this present reality. Where there is compassion, there then arises hope-filled solidarity.

Funding: This research was supported by Sogang University Research and Business Development Foundation.

Conflicts of Interest: The author declares no conflict of interest.

\section{References}

Ashley, J. Matthew. 2000. Ignacio Ellacuría and the Spiritual Exercises of Ignatius Loyola. Theological Studies 61: 16-39. [CrossRef]

Ashley, J. Matthew. 2003. Interruptions: Mysticism, Politics and Theology in the Work of Johann Baptist Metz. Notre Dame: University of Notre Dame Press.

Ashley, J. Matthew. 2006. Contemplation in the Action of Justice: Ignacio Ellacuría and Ignatian Spirituality. In Love That Produces Hope: The Thought of Ignacio Ellacuría. Edited by Kevin F. Burke and Robert Lassalle-Klein. Collegeville: Liturgical Press, pp. 144-65.

Ashley, J. Matthew. 2010. A Contemplative under the Standard of Christ: Ignacio Ellacuría's Interpretation of Ignatius of Loyola's Spiritual Exercises. Spiritus: A Journal of Christian Spirituality 10: 192-204.

Bannon, David. 2008. Unique Korean Cultural Concepts in Interpersonal Relations. Translation Journal 12. Available online: https://translationjournal.net/journal/43korean.htm (accessed on 1 April 2020).

Burke, Kevin F. 2004. The Ground Beneath the Cross: The Theology of Ignacio Ellacuría. Washington, DC: Georgetown University Press.

Chi Kim, Sandra So Hee. 2017. Korean Han and the Postcolonial Afterlives of "The Beauty of Sorrow". Korean Studies 41: 253-79. [CrossRef]

Chung, Hyun Kyung. 1989. Han-pu-ri: Doing Theology from Korean Women's Perspective. In We Dare to Dream: Doing Theology as Asian Women. Edited by Virginia Fabella and Sun Ai Lee Park. Hong Kong: Asian Women's Resource Centre for Culture and Theology, pp. 135-47.

Considine, Kevin P. 2014. Kim Chi-Ha's Han Anthropology and Its Challenge to Catholic Thought. Horizons 41: 49-73. [CrossRef]

Crowley, Paul G. 2017. The Unmoored God: Believing in a Time of Dislocation. New York: Orbis Books.

Downey, John K., and Johann Baptist Metz. 1999. Love's Strategy: The Political Theology of Johann Baptist Metz. Edited by John K. Downey. Harrisburg: Trinity Press International. 
Ellacuría, Ignacio. 1993. The Historicity of Christian Salvation. In Mysterium Liberationis: Fundamental Concepts of Liberation Theology. Edited by Ignacio Ellacuría and Jon Sobrino. New York: Orbis Books, pp. 251-89.

Ellacuría, Ignacio. 2010. A Latin American Reading of the Spiritual Exercises of Saint Ignatius". Spiritus: A Journal of Christian Spirituality 10: 205-42.

Ellacuría, Ignacio. 2013. Essays on History, Liberation, and Salvation. Edited by Michael Edward Lee. New York: Orbis Books.

Fleming, David L. 2008. What is Ignatian Spirituality? Chicago: Loyola Press.

Gutiérrez, Gustavo. 1987. On Job: God-talk and the Suffering of the Innocent. New York: Orbis Books.

Han, Kang. 2017. While the U.S. Talks of War, South Korea Shudders. The New York Times. October 7. Available online: https://www.nytimes.com/2017/10/07/opinion/sunday/south-korea-trump-war.html (accessed on 1 July 2020).

Hernandez, Jill Graper. 2018. Introduction of Special Issue “Theodicy”. Religions 9: 273. [CrossRef]

Hogue, W. 2018. The Ideal of a Radical Christian Intellectual. Religions 9: 277. [CrossRef]

Hwang, Sok-yong. 2005. The Guest. Translated by Kyung-Ja Chun, and Maya West. New York: Seven Stories Press. Joh, Wonhee Anne. 2006. Heart of the Cross: A Postcolonial Christology. Louisville: Westminster John Knox Press.

Kim, A. E. 2018. Minjung Theology in Contemporary Korea: Liberation Theology and a Reconsideration of Secularization Theory. Religions 9: 415. [CrossRef]

Lee, Jung Young. 1995. Marginality: The Key to Multicultural Theology. Minneapolis: Fortress Press.

Losada-Sierra, M. 2019. Memory and History: The Overcoming of Traditional Theodicy in Levinas and Metz. Religions 10: 657. [CrossRef]

Metz, Johann Baptist. 1968. Poverty of Spirit. Translated by John Drury. New York: Paulist Press.

Metz, Johann Baptist. 1969. Theology of the World. Translated by William Glen-Doepel. London: Herder and Herder.

Metz, Johann Baptist. 1978. Followers of Christ: The Religious Life and the Church. Translated by Thomas Linton. New York: Paulist Press.

Metz, Johann Baptist. 1998. A Passion for God: The Mystical-Political Dimension of Christianity. Translated by J. Matthew Ashley. New York: Paulist Press.

Metz, Johann Baptist. 1997. Johann Baptist Metz. In How I Have Changed: Reflections on Thirty Years of Theology. Translated by John Bowden. Edited by Jürgen Moltmann. London: SCM Press, pp. 31-36.

Metz, Johann Baptist. 2007. Faith in History and Society: Toward a Practical Fundamental Theology. Translated by J. Matthew Ashley. New York: Herder and Herder.

Metz, Johann Baptist, and Karl Rahner. 1980. The Courage to Pray. Translated by Ermutigung zum Gebet. New York: Crossroad.

O'Connor, Kathleen M. 2002. Lamentations and the Tears of the World. New York: Orbis Books.

Park, Andrew Sung. 1989. Theology of Han. Quarterly Review 9: 48-62.

Park, Kyong-ni. 1994. The Feelings and Thoughts of the Korean People in Literature: Keynote Speech at a Special Colloquium Organized by the University of Paris 7 and the Korean Arts and Foundation. Available online: http://www.koreantranslation.com/REPOSITORY/HanTheSoulofKoreanLiterature/tabid/ 1557/Default.aspx (accessed on 10 March 2020).

Pope Francis. 2013a. Visit to Lampedusa. Homily of Holy Father Francis (8 July 2013). Available online: http://www.vatican.va/content/francesco/en/homilies/2013/documents/papa-francesco_20130708_ omelia-lampedusa.html (accessed on 31 August 2020).

Pope Francis. 2013b. Apostolic Exhortation Evangelii Gaudium (24 November 2013). Available online: http://www.vatican.va/content/francesco/en/apost_exhortations/documents/papa-francesco_esortazioneap_20131124_evangelii-gaudium.html (accessed on 1 May 2020).

Pope Francis. 2018. General Audience. St. Peter's Square (25 April 2018). Available online: http://www.vatican.va/ content/francesco/en/audiences/2018/documents/papa-francesco_20180425_udienza-generale.html (accessed on 3 February 2020).

Prinz, Julia D. E. 2007. Endangering Hunger for God: Johann Baptist Metz and Dorothee Sölle at the Interface of Biblical Hermeneutic and Christian Spirituality. Berlin: LIT.

Puhl, Louis J. 1968. The Spiritual Exercises of St. Ignatius: Based on the Studies in the Language of the Autograph. Chicago: Loyola University Press.

Ryu, Youngju. 2015. Truth or Reconciliation? The Guest and the Massacre That Never Ends. Positions 23: 633-64. [CrossRef] 
Schuster, Ekkehard, and Reinhold Boschert-Kimmig. 1999. Hope Against Hope: Johann Baptist Metz and Elie Wiesel Speak Out on the Holocaust. Translated by J. Matthew Ashley. New York: Paulist Press.

Sobrino, Jon. 2006. Ignacio Ellacuría, the Human Being and the Christian: Taking the Crucified People Down from the Cross. In Love That Produces Hope: The Thought of Ignacio Ellacuría. Edited by Kevin F. Burke and Robert Lassalle-Klein. Collegeville: Liturgical Press, pp. 1-67.

Sobrino, Jon, and Ignacio Ellacuría. 1990. Companions of Jesus: The Jesuit Martyrs of El Salvador. New York: Orbis Books.

Song, C. S. 1986. Theology from the Womb of Asia. New York: Orbis Books.

Suh, Nam-dong. 1983. Towards a Theology of Han. In Minjung Theology: People as the Subjects of History. Edited by Commission on Theological Concerns of the Christian Conference of Asia. New York: Orbis Books, pp. 55-69.

Suleski, Ronald. 2007. The Guest (review). Azalea: Journal of Korean Literature E Culture 1: 289-93.

Wiesel, Elie. 1969. Night. Translated by Stella Rodway. New York: Avon Books.

(C) 2020 by the author. Licensee MDPI, Basel, Switzerland. This article is an open access article distributed under the terms and conditions of the Creative Commons Attribution (CC BY) license (http://creativecommons.org/licenses/by/4.0/). 